\title{
THE IMPACT OF THE ECOHYDROLOGIC CONDITIONS OF THREE GORGES RESERVOIR ON THE SPAWNING ACTIVITY OF FOUR MAJOR CHINESE CARPS IN THE MIDDLE OF YANGTZE RIVER, CHINA
}

\author{
GUO, W. X. - JiN, Y. G. - ZHAO, R. C. - WANG, H. X. \\ ${ }^{I}$ North China University of Water Resources and Electric Power, Zhengzhou 450045, China \\ ${ }^{2}$ Key Laboratory of Water Resources Conservation and Intensive Utilization in Yellow River \\ Basin of Henan Province, Zhengzhou 450045, China \\ *Corresponding author \\ e-mail:whxzju@163.com; phone: +86-135-9257-3656 \\ (Received $2^{\text {nd }}$ Jun 2020; accepted $29^{\text {th }}$ Jul 2021)
}

\begin{abstract}
Black carp (Mylopharyngodon piceus), grass carp (Ctenopharyngodon idella), silver carp (Hypophthalmichthys molitrix) and bighead carp (Aristichthys nobilis) are the four major Chinese carps and are migratory fishes living in rivers and lakes in the Yangtze River of China. The flow regime alternation of rivers has an impact on the spawning and reproduction conditions of four major Chinese carps in the lower reaches of the Three Gorges Reservoir. To investigate the changes in hydrological conditions and spawning and reproduction performances of four major Chinese carps during their spawning period before and after impoundment of Three Gorges Reservoir, a quantitative analysis of the relevance between such hydrological parameters as flow, water level, sediment concentration and water temperature of Yichang Station and larva runoff of the four species during their spawning period was carried out. As suggested by the results, when four major Chinese carps are spawning, the proper hydrological parameters would be $11,000-15,000 \mathrm{~m}^{3} / \mathrm{s}$ for flow, $43.0-46.0 \mathrm{~m}$ for water level, $0.01-0.21 \mathrm{~kg} / \mathrm{m}^{3}$ for sediment concentration and 4-8 $\mathrm{d}$ for water rise, and $22-24^{\circ} \mathrm{C}$ for water temperature. Among those values, water rise and sediment concentration appear to be in significant positive correlation with the larvae abundance of four major Chinese carps, and thus remain critical factors. After the impoundment of Three Gorges Reservoir, the declining trend in flow, water level and water temperature during the spawning period of four major Chinese carps is not significant when compared with that in sediment concentration (by over 98\%). The spawning and reproduction time of four species also gets retarded due to the late-coming proper water temperature, so does the spawning scale. The proportions of four carps also change a lot, with silver carp ascending to be at the highest ratio among them. This study can provide a reference for the protection of important fishes in the lower reaches of Three Gorges Reservoir.
\end{abstract}

Keywords: Three Gorges Reservoir, Yichang Station, eco-hydrological conditions, four major Chinese carps, spawning ground

\section{Introduction}

In past decades, hydraulic engineering, a much-disputed human activity, is gaining more and more attention (Ban et al., 2014). On one hand, it does bring economic benefits such as flood control, irrigation, power generation, shipping, industry and urban domestic water to human beings (Poff et al., 1997; Jiang et al., 2014); on the other, it also changes 
the natural hydrological conditions of rivers and overturns their original continuity, producing some negative effect on the species composition and adaptability of biocoenosis within the reaches in question (Cai et al., 2018; Grill et al., 2019). As the hydraulic engineering development gets enhanced, the original hydrological conditions of rivers will definitely suffer a more severe impact, and the balance of riverine ecosystem will be thus destroyed (Xue et al., 2017). As a result, to study the impact of hydraulic engineering development on hydrological conditions and ecology of rivers turns out to be a hot spot in the current riverine eco-hydrology research field (Li et al., 2011; Wang et al., 2018).

Three Gorges Reservoir is situated at the middle reaches of Yangtze River. Within its downstream segment from Yichang to Chenglingji, there is a spawning site for the important commercial fishes, namely "four major Chinese carps" which accounts for $42.7 \%$ of total spawning capacity along the River. This is one of the most important natural reproduction zones for Chinese carps in Yangtze River (Guo et al., 2011; Li et al., 2013). The impoundment at Three Gorges Reservoir has produced a significant effect on the spawning and reproduction of four major Chinese carps, which is analyzed by some scholars. Li et al. (2012) deduced the principal hydrological parameters affecting spawning activity of fishes by figuring out the flow demand of four major Chinese carps in Yangtze River by using the variational method. By defining a series of water temperature parameters, Cai et al. (2017) analyzed the change in reproduction time of four major Chinese fishes and water temperature parameters before and after the impoundment of Three Gorges Reservoir and suggested that low temperature of discharging water may be held responsible for the delay of reproduction time. Peng et al. (2012) revealed the possible adverse effect of dissolved gas supersaturation resulting from post-impoundment flood discharge at Three Gorges Reservoir on the spawns and larval fishes of four major Chinese carps. Apart from those, there are also some other related studies (Zhao et al., 2012; Yang et al., 2017).

Fish conservation has been the focus of discussion on many environmental issues. The construction of reservoir dam has changed the natural rhythm of surface runoff, resulting in significant changes in the physical environment, chemical environment, biome structure and function of river ecosystem (Chen et al., 2017; Herath et al., 2020). According to statistics, 85 of the 113 major rivers in Canada, the United States, Europe and the former Soviet Union were affected by major construction, resulting in changes in downstream hydrological processes, fragmentation or disappearance of aquatic habitats, and declining fish diversity and resource levels ( $\mathrm{Li}$ et al., 2018). Over the past hundred years, dam construction has led to the threat or extinction of nearly 1,800 species of identifiable freshwater fish worldwide (Agostinho et al., 2008; Dai et al., 2017). At present, the impact of hydropower development on fish has become the focus of attention of all sectors of society, and the protection of fish habitat has become an important part of the ecological protection system of hydropower engineering construction (Feng et al., 2013; Zhang et al., 2017, 2018). 
Since a majority of previous studies concentrate on single hydrological parameter, whereas spawning and reproduction behaviors of four major Chinese carps are under the influence of multiple factors. In this study, the hydrological parameters and the larvae runoff monitoring data downstream Three Gorges Reservoir were investigated to evaluate the impact of the eco-hydrologic conditions of Three Gorges Reservoir on the spawning activity of four major Chinese carps. Our objectives were (1) to determine the correlation between the hydrological conditions and the spawning activity of four major Chinese carps; (2) to analyze the variation of hydrological conditions during spawning period of four major Chinese carps before and after impoundment at Three Gorges Reservoir; (3) to assess the impacts of Three Gorges Reservoir on the spawning and reproduction activities of four major Chinese carps. The study can provide a theoretical basis for rvierine ecosystem protection of the Yangtze River.

\section{Study area and methods}

\section{Sampling location and time}

The present study selected the spawning site of four major Chinese carps in lower reaches of Three Gorges Reservoir as the research area. Ever since the founding of the People's Republic of China, three influential investigations concerning the reproductive habits, spawns, larval fish development, spawning site distribution, and spawning scale of four major Chinese carps have been conducted during 1958-1966, 1981-1986 and 1997-2010, respectively. During those investigations, a great number of monitoring data were generated. In accordance with a survey by Institute of Hydrobiology, there were altogether 30 spawning sites for four major Chinese carps in Tianjia Township from Chongqing to Hubei before Gezhou Dam Hydro-Junction was built, among which 11 were located in the segment from Yichang to Chenglingji with $42.7 \%$ of total spawning quantity along the river. Those spawning sites are the habitats of spawning and reproduction for four major Chinese carps with critical ecological functions and constitute important eco-functional regions in the biological resources of Yangtze River. After Gezhou Dam was completed, the major spawning sites above the dam include Xinshi Township, Pingshan, Anbian, Chongqing, Changshou, Wuling, Gaojia Township, Zhongxian County, Wushan, Badong and Liantuo, while those below the dam are Yichang-Zhicheng Cross-section, Jingshan-Jianli Cross-section, Chenglingji-E'ChengWuxue Cross-section, Jiujiang-Hukou-Pengze Cross-section. From Yichang to Chenglingji along Yangtze River, there are 10 spawning sites for four major Chinese carps, among which 9 are located at Jianli and the cross-sections above it. The relative positions of spawning sites are demonstrated in Fig. 1 . 


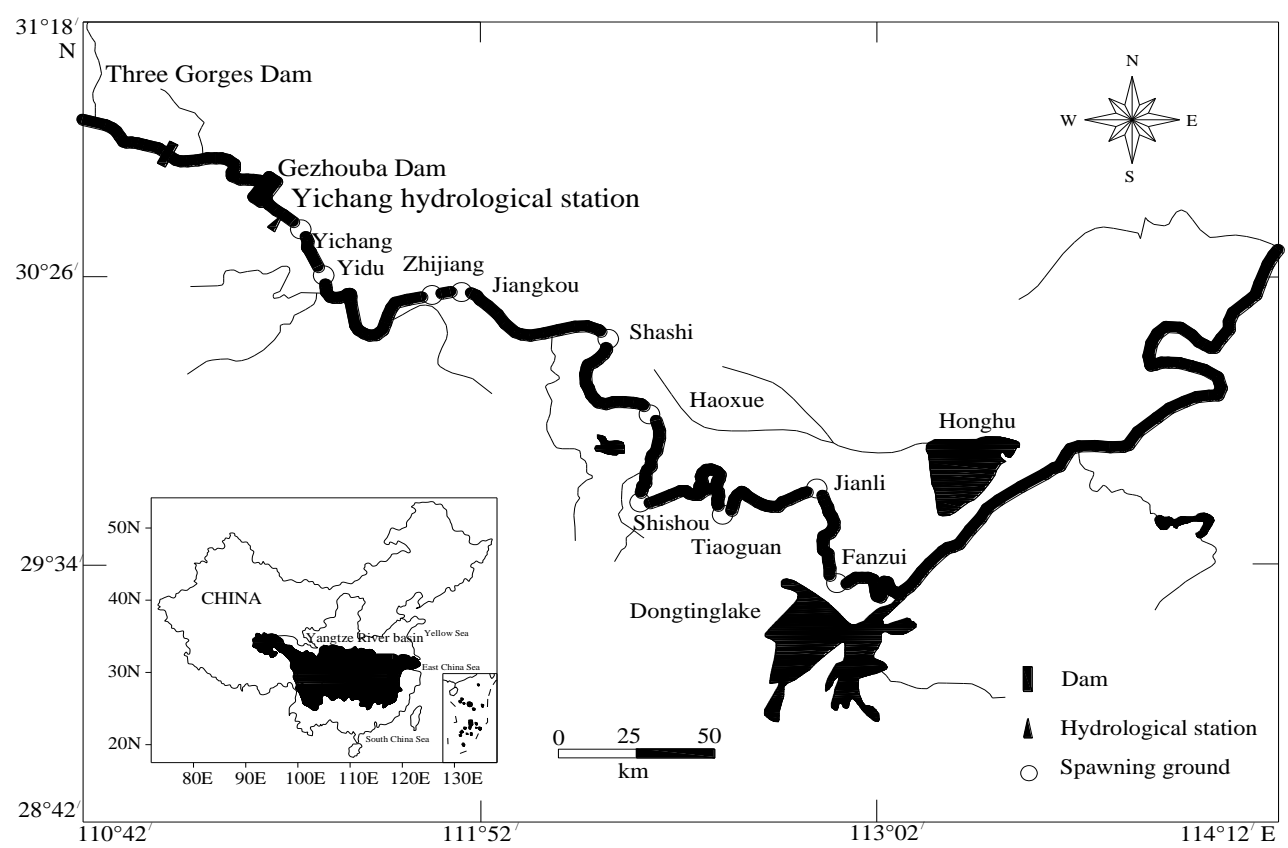

Figure 1. Distribution of spawning sites of four major Chinese carps in middle reaches of Yangtze River

In the Yangtze River, silver carp usually reproduce in late April to early July, and middle May to middle June is the best time for breeding (Yi et al., 1988). The breeding activity of bighead carp is usually from May to July, slightly later than that of silver carp. The reproductive period of grass carp is usually earlier than that of black carp. Generally spawning begins in late April or early May and ends in late June or early July. The spawning period of black carp is from May to July, a little later than that of grass carp and silver carp. Spawning requirements of four major Chinese carps are specific and rigorous: they typically spawn in large and turbid rivers; the lowest water temperature for spawning is $18^{\circ} \mathrm{C}$, with a peak occurring at $21-24^{\circ} \mathrm{C}$; an increase in the river flow is the key triggering factor to spawning. Eggs and larvae need to drift in the freeflowing river reaches for at least $100 \mathrm{~km}$ until they grow large enough to migrate into the nursery habitats of connecting lakes, such as Dongting Lake and Poyang Lake (Zhang et al., 2000; Chen et al., 2009).

The spawning grounds of four major Chinese carps are generally located in the area of curved river, wide and narrow river surface and complicated riverbed topography, or there are sandbars and reefs in the middle of the river, or sandy beaches and rocky beaches along the river. In these regions, the flow direction and velocity are various, and the flow pattern is extremely turbulent. Special environmental conditions form complex and diverse flow characteristics, which provide the environmental factors needed for the fish to spawn. Figure 2 are the photos of the typical spawning grounds. 

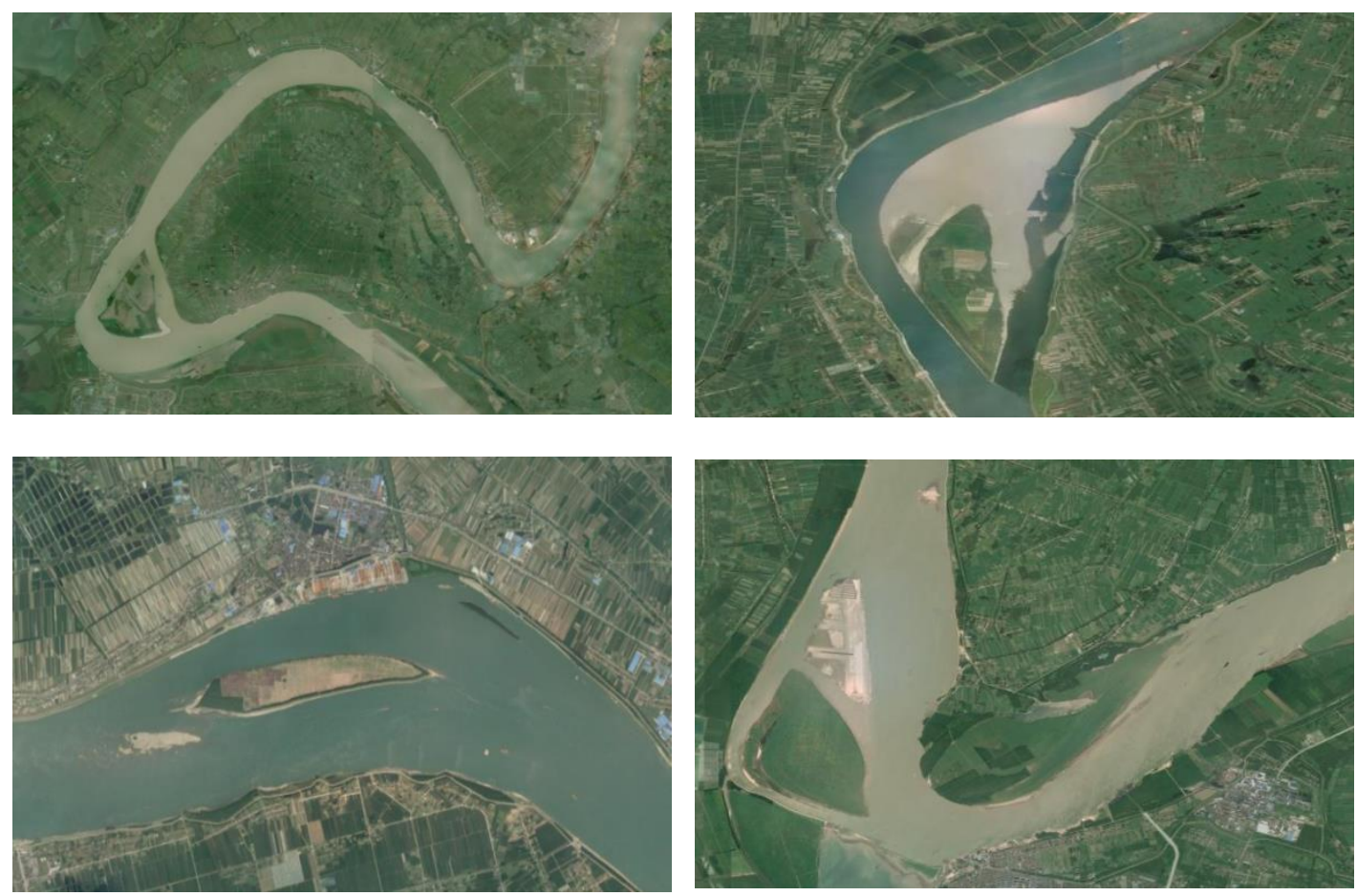

Figure 2. The photos of typical spawning grounds

\section{Data and statistical analysis}

Survey and monitoring of carps' larvae

Every year from 1997 to 2005, sampling was conducted daily between May 1 and June 30. Samples were collected twice daily, once between 9:00 and 11:00, and once between 15:00 and 17:00. The gears used for capture of larvae were a ring net and a trap net. A ring net was used to gather larvae and eggs from different water depths. The ring net consisted of a round mouth formed by a steel loop (diameter $=50 \mathrm{~cm}$; area $=0.1963 \mathrm{~m}^{2}$ ), a conical net and a collection bucket. The netting was made of fine silk with the grid size of $0.5 \mathrm{~mm}$. A steel frame supported the whole body. A flow meter was fixed in the mouth of the net. A large weight was attached to the bottom of the frame to assist sinking the net into the flowing water. Trap nets were used to collect eggs and larvae from near water surface in littoral areas.

The underlying data for this study are measured hydrological data and seedling monitoring data for the spawning period of fish in protected areas for 2009-2016, and the sources and related processing of the data are as follows: Since 2009, the Yangtze River Fisheries Research Institute of the Chinese Academy of Aquatic Sciences has carried out routine monitoring of fish resources in protected areas, including the monitoring points of the early fish resources in the upper reaches of the Yangtze River in the Jiangjin district of several river sections $\left(\mathrm{E} 106^{\circ} 15^{\circ}, \mathrm{N} 29^{\circ} 18^{\prime}\right)$, fish eggs are collected from May 1 to July 10, each day from 09:00-11:00 a.m. and 15:00-17:00 p.m. 


\section{Data processing and evaluation}

The field data should record the parameters of water depth, current velocity and sediment of each fish sample. Fish samples were clearly classified by species and age, and their length and weight were recorded. At the same time, other habitat parameters such as type of deep pool, cover or shelter were recorded. Figure 3 is the distribution of the current velocity in the spawning ground of a certain fish in a river. Unless the observed data is very large, the frequency distribution curve will not be very smooth, so the data can be grouped by a certain width of interval to increase the smoothness of the curve. The formula of interval width is shown in (1). The fitness curve can be obtained from the midpoint of each interval of a simple continuous frequency histogram. Smooth the curve further if necessary (Figure 3). The data can also be standardized by dividing by the maximum of the curve to get a fitness of $0 \sim 1$. Table 1 shows the results of an analysis of a field observation.

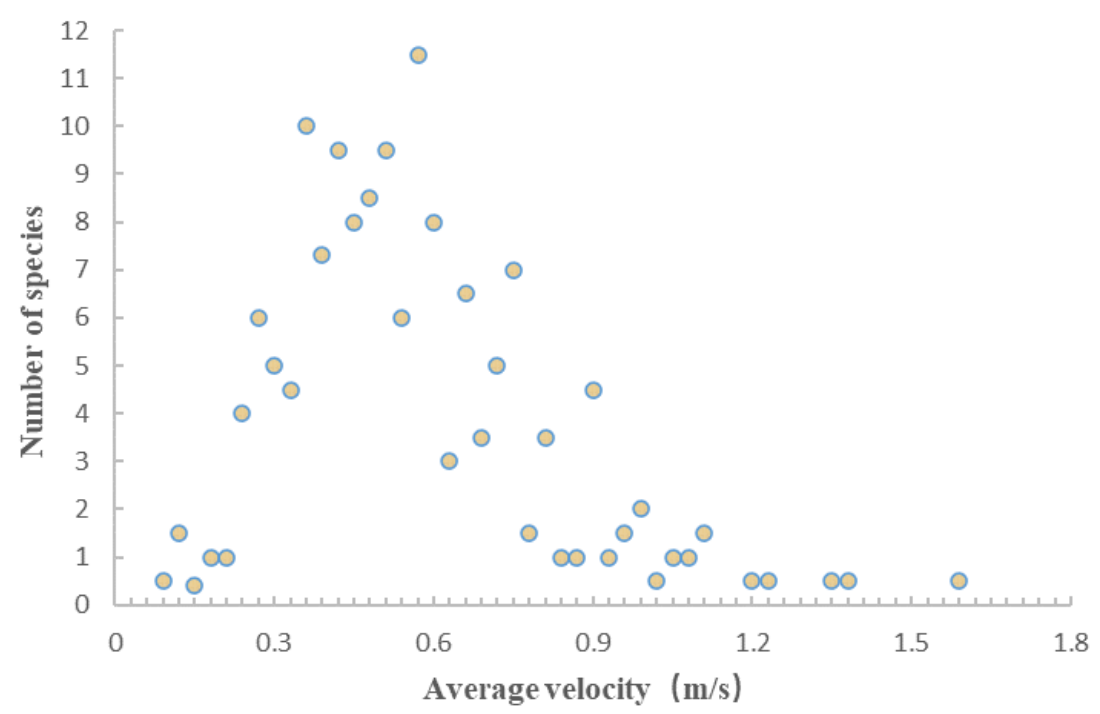

Figure 3. Velocity distribution in fish spawning ground

Table 1. Field observation data and preference function of fish depth preference

\begin{tabular}{c|c|c|c|c|c|c|c}
\hline $\begin{array}{c}\text { Depth } \\
\text { /cm }\end{array}$ & $\begin{array}{c}\text { Area } \\
/ \mathrm{m}^{2}\end{array}$ & Number & $\mathrm{N} / \mathrm{N}_{\max }$ & $\mathrm{A} / \mathrm{A}_{\max }$ & $\mathrm{N}_{\text {norm }} / \mathrm{A}_{\text {norm }}$ & Preference & $\begin{array}{c}\text { Smoothing } \\
\text { Preference }\end{array}$ \\
\hline $0 \sim 10$ & 100 & 0 & 0 & 1.00 & 0 & 0 & 0 \\
$10 \sim 20$ & 70 & 19 & 0.51 & 0.70 & 0.73 & 0.37 & 0.50 \\
$20 \sim 30$ & 50 & 37 & 1.00 & 0.50 & 2.00 & 1.00 & 1.00 \\
$30 \sim 40$ & 45 & 31 & 0.84 & 0.45 & 1.86 & 0.93 & 1.00 \\
$40 \sim 50$ & 60 & 25 & 0.68 & 0.60 & 1.13 & 0.56 & 0.60 \\
$50 \sim 60$ & 40 & 13 & 0.35 & 0.40 & 0.88 & 0.44 & 0.45 \\
$60 \sim 70$ & 30 & 5 & 0.14 & 0.30 & 0.45 & 0.23 & 0.30 \\
$70 \sim 80$ & 25 & 3 & 0.08 & 0.25 & 0.32 & 0.15 & 0.15 \\
$80 \sim 90$ & 20 & 3 & 0.08 & 0.20 & 0.41 & 0.20 & 0.15 \\
$90 \sim 100$ & 10 & 0 & 0 & 0.10 & 0 & 0 & 0 \\
\hline
\end{tabular}


The formula for interval width is

$$
I=\frac{R}{I+3.908 \lg N}
$$

Formula: I for the best spacing size, $\mathrm{R}$ for the observed value range, $\mathrm{n}$ for the observed number of species.

The frequency data for habitat use need only be plotted at simple locations based on measured data, while the habitat preference function must include the availability of different habitat quality, as shown in Table 1. The number of individuals divided by the proportion of the total habitat area (or volume) in some ranges can yield very different fitness curves. If the proportion of a category is too small, the ratio may be too large, so species abundance and area need to be standardized first.

In this study, the hydrological data about Yichang Station in lower reaches of Yangtze River were placed under an analysis. This hydrological station is of the control station of Three Gorges Reservoir, which can well reflect the change characters of the flow at the four major Chinese carps' spawning sites in the lower reaches of Yangtze River. Besides, the data about water level, flow rate, water temperature and sediment concentration at Yichang Station (during 1956-2016) have a long history and are thus highly representative. The four major Chinese carps in the downstream Jianli cross-section of Three Gorges Reservoir were selected here as the research objects. This cross-section is situated at about $210 \mathrm{~km}$ downstream from Yichang, and the spawning site extended by $25 \mathrm{~km}$. The hydrological data about Yichang Station were collected from Hydrological Yearbook of Yangtze River, while the larvae runoff monitoring data from Yangtze River Three Gorges Ecological and Environmental Monitoring Bulletin (during 1997-2016).

\section{Results}

Analysis of correlation between the spawning and reproduction of four major Chinese carps and the hydrological conditions

From 1997 to 2016, altogether 26 batches of four major Chinese carps were monitored as spawning in corresponding sites of Jianli, and the water level, flow rate, sediment concentration and water temperature data of that day were either measured or collected on site for an analysis of the average, minimum, maximum values as well as the suitable range of flow rate during the spawning period of four major Chinese carps (Table 2).

To conduct statistics of suitable range of flow rate during spawning period of four major Chinese carps, the spawning frequency of those fishes in the major flow rate characteristics were recorded to obtain the frequency curves of all the hydrological characteristic indicators as shown in Fig. 4.

As revealed by an analysis of four major Chinese carps' spawning and reproduction conditions, the spawning activity of them is almost all done during flooding season. 


$$
-4320-
$$

Flooding is a process containing changes in a string of hydrological elements, including elevated water level and flow, accelerated flow rate, reduced transparency, and disorderly flow state, during which flow rate is accelerated so that four major Chinese carps are stimulated to become mature and parent fishes begin spawning and discharging seminal fluid. As the water levels lowers and flow rate decelerates, most of the reproductive activities come to a stop.

Table 2. Principal hydrological characteristics of spawning cross-sections for four major Chinese carps

\begin{tabular}{|c|c|c|c|c|c|c|c|}
\hline Eigenvalues & $\begin{array}{l}\text { Flow } \\
\left(\mathrm{m}^{3} / \mathbf{s}\right)\end{array}$ & $\begin{array}{l}\text { Water } \\
\text { level } \\
(\mathrm{m})\end{array}$ & $\begin{array}{c}\text { Sediment } \\
\text { concentration } \\
\left(\mathbf{k g} / \mathbf{m}^{\mathbf{3}}\right)\end{array}$ & $\begin{array}{c}\text { Water } \\
\text { temperature } \\
\left({ }^{\circ} \mathrm{C}\right)\end{array}$ & \begin{tabular}{|c|} 
Rise rate of \\
flow \\
$\left(\mathbf{m}^{3} / \mathbf{s} \cdot \mathbf{d}\right)$
\end{tabular} & $\begin{array}{c}\text { Rise rate of } \\
\text { water-level } \\
(\mathbf{m} / \mathbf{d})\end{array}$ & $\begin{array}{c}\text { Flooding } \\
\text { period } \\
\text { (d) }\end{array}$ \\
\hline Means & 17529 & 45.17 & 0.378 & 23.4 & 1615 & 0.54 & 7 \\
\hline Minimum & 7958 & 41.4 & 0.003 & 20.9 & 120 & 0.06 & 2 \\
\hline Maximum & 34700 & 49.88 & 1.41 & 25.8 & 5675 & 1.60 & 15 \\
\hline $\begin{array}{l}\text { Standard } \\
\text { deviation }\end{array}$ & 5695 & 1.9 & 0.44 & 1.3 & 1523 & 0.39 & 3 \\
\hline Suitable range & $\begin{array}{l}11000- \\
15000\end{array}$ & $43-46$ & $0.01-0.21$ & $22-24$ & $100-1000$ & $0.3-0.55$ & $4-8$ \\
\hline
\end{tabular}

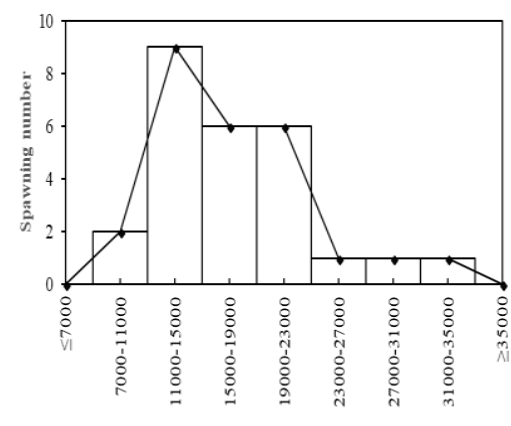

Flow range $\left(\mathrm{m}^{3 / 5}\right)$

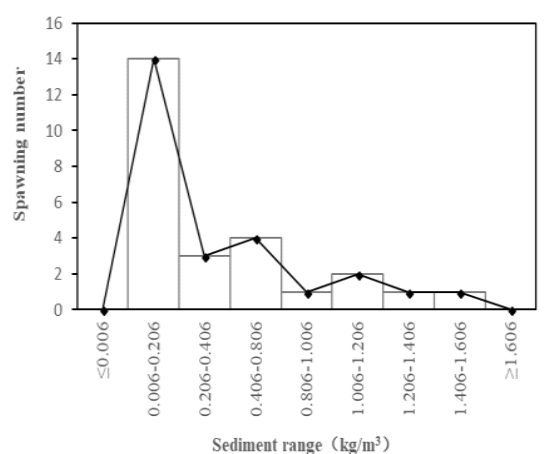

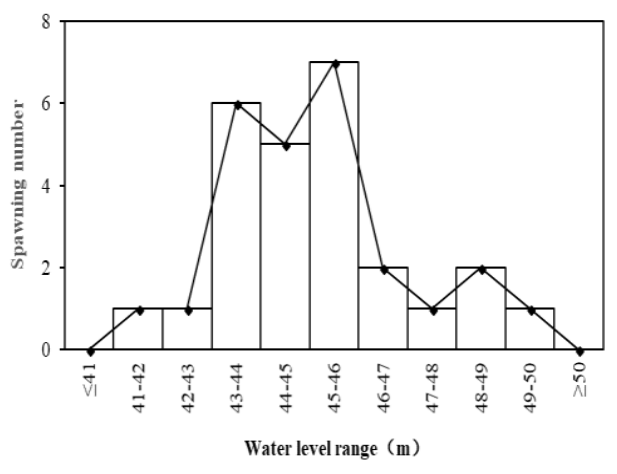

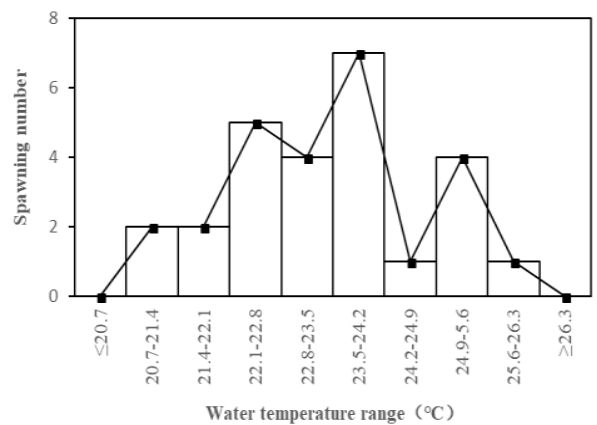

Figure 4. Frequency curves of the hydrological indicators 


$$
-4321-
$$

To quantify the relation between spawning quantity of four major Chinese carps and hydrologically influential factors, we fitted the larvae runoff and hydrological factors during spawning period. The fitting relationship between larvae runoff and flooding period can be expressed as $y=1.1842 x-0.4614$ with a coefficient of association of 0.58 and is significant positive (Fig. 5), and that between larvae runoff and sediment concentration expressed as $y=7.4458+1.8296$ with a coefficient of association of 0.58 and is significant positive (Fig. 6). The correlations between larvae runoff and other hydrological indicators are less significant. It can be thus inferred that flooding period and sediment concentration are two important factors affecting the spawning quantity of four major Chinese carps.

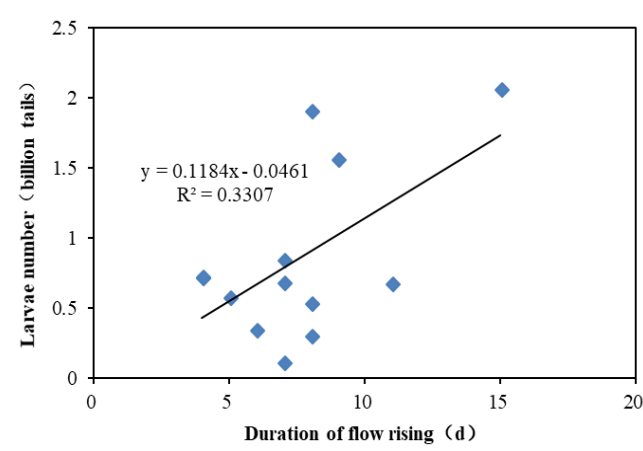

Figure 5. The correlation curve of Duration of flow rising vs. larvae number

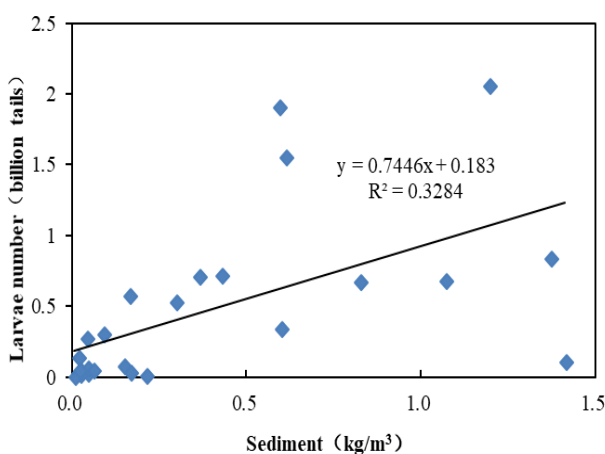

Figure 6. The correlation curve of sediment vs. larvae number

\section{Change in hydrological conditions during spawning season of four major Chinese carps before and after impoundment at Three Gorges Reservoir}

This study highlights the change in the flow rate, water level, water temperature and sediment concentration of Yichang Station during the prosperous spawning months, May and June, of four major Chinese carps before and after the impoundment by Three Gorges Reservoir. To check the significance of change trend in all the hydrological factors during spawning season of four major Chinese carps, Mann-Kendall trend test was performed and the results are provided in Table 3. According to the results of test, there is no significant change in the flow rate during the spawning season of four major Chinese carps, but water level, water temperature and sediment concentration change considerably. Water level and water temperature in May passed $95 \%$ confidence test at a significant declining trend and while water level in June and sediment concentration in May and June passed $99 \%$ confidence test with a significant declining trend. It can be thus seen that during the spawning season of four major Chinese carps, such hydrological factors as 
water level, water temperature and sediment concentration undergo a significant change which can be attributed to the impoundment at Three Gorges Reservoir.

Table 3. Analytic table of hydrological indicators' trend at Yichang Station during spawning season of four major Chinese carps

\begin{tabular}{c|c|c|c|c}
\hline $\begin{array}{c}\text { Hydrological } \\
\text { indicators }\end{array}$ & Month & $Z_{c}$ & Rulebook & Trend \\
\hline \multirow{2}{*}{ Flow } & May & 0.34 & $\left|Z_{c}\right|<1.96$ & Increase \\
& June & -0.29 & $\left|Z_{c}\right|<1.96$ & Decrease \\
Water level & May & -2.40 & $1.96<\left|Z_{c}\right|<2.58$ & Decrease* \\
& June & -3.90 & $\left|Z_{c}\right|>2.58$ & Decrease** \\
Water temperature & May & -2.19 & $1.96<\left|Z_{c}\right|<2.58$ & Decrease* \\
Sediment & June & -1.78 & $\left|Z_{c}\right|<1.96$ & Decrease \\
concentration & May & -7.95 & $\left|Z_{c}\right|>2.58$ & Decrease** \\
\hline
\end{tabular}

* Significant trend at 0.05 confidence level; ** Significant trend at 0.01 confidence level

To analyze the hydrological impact of impoundment at Three Gorges Reservoir on spawning season of four major Chinese carps in 2003, we summarized and analyzed the change in all the hydrological elements before and after the impoundment at Three Gorges Reservoir (Table 4). It can be inferred from Table 3 that after impoundment at Three Gorges Reservoir, all the hydrological factors displayed a declination in varying degrees. The average flow rate in June of several years dropped by $960 \mathrm{~m}^{3} / \mathrm{s}(5.32 \%)$ when compared with that before dam construction; average water level in May and June of several years declined by $8.24 \%$ and $3.15 \%$, respectively; the declination in sediment concentration was most striking by being $98.11 \%\left(0.52 \mathrm{~kg} / \mathrm{m}^{3}\right)$ and $97.94 \%\left(0.95 \mathrm{~kg} / \mathrm{m}^{3}\right)$ in May and June, respectively. Therefore, water level doesn't affect much the spawning and reproduction of four major Chinese carps. The declination in flow rate in May does inhibit the river flow during the spawning season of those fishes, but water temperature drop directly postpones their spawning time so that they have greatly reduced time for spawning. The dramatic decrease in sediment concentration may change the riverbed configuration in spawning sites of those carps, affecting their habitat conditions and thus their spawning and reproduction in a negative way.

\section{Change in spawning and reproduction of four major Chinese carps before and after impoundment at Three Gorges Reservoir}

Analysis of four major Chinese carps' spawning time before and after impoundment at Three Gorges Reservoir

On the basis of spawning monitoring data about four major Chinese carps in past years, the spawning activity of those fishes begins as early on April 28 and late on May 10 and 


$$
-4323-
$$

ends as early on June 15 and late on July 5. The spawning and reproduction of four major Chinese carps was found to be closely related to water temperature which mainly ranges between $14^{\circ} \mathrm{C}$ and $30^{\circ} \mathrm{C}$ from late April to late July at Yichang Hydrological Station. In natural conditions, four major Chinese carps begin spawning at $18^{\circ} \mathrm{C}$ and remain most actively reproductive at $20-24^{\circ} \mathrm{C}$, but end the activity when the temperature is below $18^{\circ} \mathrm{C}$. Fig. 7 illustrates the change in lowest water temperature at Yichang Station during the spawning and reproduction period of four major Chinese.

Table 4. Hydrological condition of spawning grounds of four major Chinese carps at the Yichang station in May and June

\begin{tabular}{l|c|c|c|c|c}
\hline \multicolumn{2}{c|}{ Month } & $\begin{array}{c}\text { Flow } \\
\left(\mathbf{m}^{3} / \mathbf{s}\right)\end{array}$ & $\begin{array}{c}\text { Water level } \\
(\mathbf{m})\end{array}$ & $\begin{array}{c}\text { Water temperature } \\
\left({ }^{\circ} \mathbf{C}\right)\end{array}$ & $\begin{array}{c}\text { Sediment } \\
\text { concentration } \\
\left(\mathbf{k g} / \mathbf{m}^{3}\right)\end{array}$ \\
\hline \multirow{4}{*}{ May } & Per-impact & 11560 & 41.22 & 21.24 & 0.53 \\
& Post-impact & 12315 & 40.98 & 19.49 & 0.01 \\
& Change & 755 & -0.24 & -1.75 & -0.52 \\
& Change degree & $6.53 \%$ & $-0.59 \%$ & $-8.24 \%$ & $-98.11 \%$ \\
\hline \multirow{4}{*}{ June } & Per-impact & 18060 & 43.62 & 23.47 & 0.97 \\
& Post-impact & 17100 & 42.66 & 22.73 & 0.02 \\
& Change & -960 & -0.96 & -0.74 & -0.95 \\
& Change degree & $-5.32 \%$ & $-2.20 \%$ & $-3.15 \%$ & $-97.94 \%$ \\
\hline
\end{tabular}

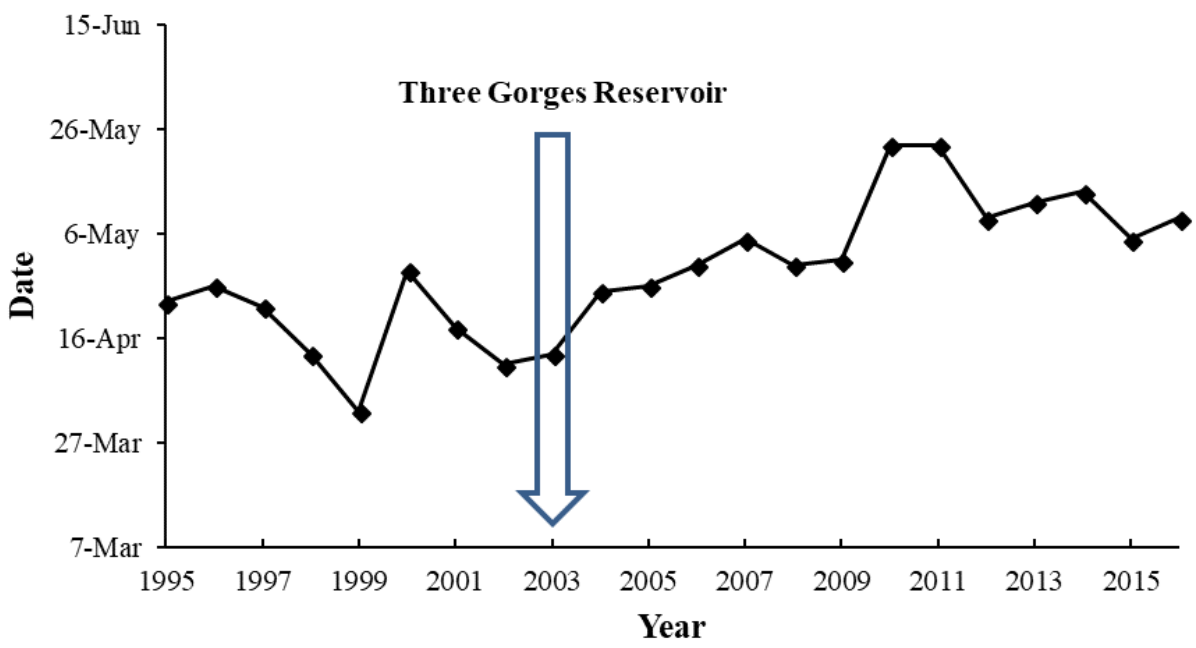

Figure 7. Change in date of the lowest water temperature during spawning and reproduction season of four major Chinese carps over the years

By checking the change in date on which daily average water temperature is stabilized at $18^{\circ} \mathrm{C}$ during spawning and reproduction period of four major Chinese carps before and 
after impoundment at Three Gorges Reservoir, we can find that during this period, little change occurs in term of effect of impoundment by the dame on the water temperature. After Three Gorges Reservoir begins impoundment, the water temperature at Yichang Station in April and May is lower than that in natural state before the impoundment by $2^{\circ} \mathrm{C}$. During 2004-2008, when four major Chinese carps begin spawning and reproduction, the date on which daily average temperature of Yichang Station gets stabilized at $18^{\circ} \mathrm{C}$ are April 25, 26, 30, May 5 and April 30, respectively, later than that before impoundment by 10 days or so. During 2009-2013, the dates are May 10, 23, 23, 9 and 12, respectively, later than that after the impoundment by 10 days. Therefore, the impoundment at Three Gorges Reservoir does cause a postponement in the spawning and reproductive activities of four major Chinese carps, and the average postponement is about 20 days. It produces certain effect on their spawning activity which is postponed from the late April before impoundment to middle and late May and even early June after that.

Analysis of spawning scale offour major Chinese carps before and after the impoundment at Three Gorges Reservoir

In accordance with 1997 Yangtze River Three Gorges Project Ecological and Environmental Monitoring Bulletin from Chongqing to Tianjia Township, among which 11 are located from Chongqing to Yichang and 11 in the $400 \mathrm{~km}$ Yichang-Chenglingji Cross-section downstream of the dam reservoir area, and 8 in Chenglingji-Wuxue Crosssection. Before the impoundment at Three Gorges Reservoir, the larval fishes on Jianli cross-section mainly come from the spawning sites of four major Chinese carps above Gezhou Dam and reached a peak in term of spawning quantity in 1986 with larvae runoff being 7.2 billion. The larvae runoff monitoring results about four major Chinese carps on Jianli cross-section before and after the impoundment by Three Gorges Reservoir are derived from Yangtze River Three Gorges Project Ecological and Environmental Monitoring Gazette over the years (1997-2016) and provided in Fig. 8. 


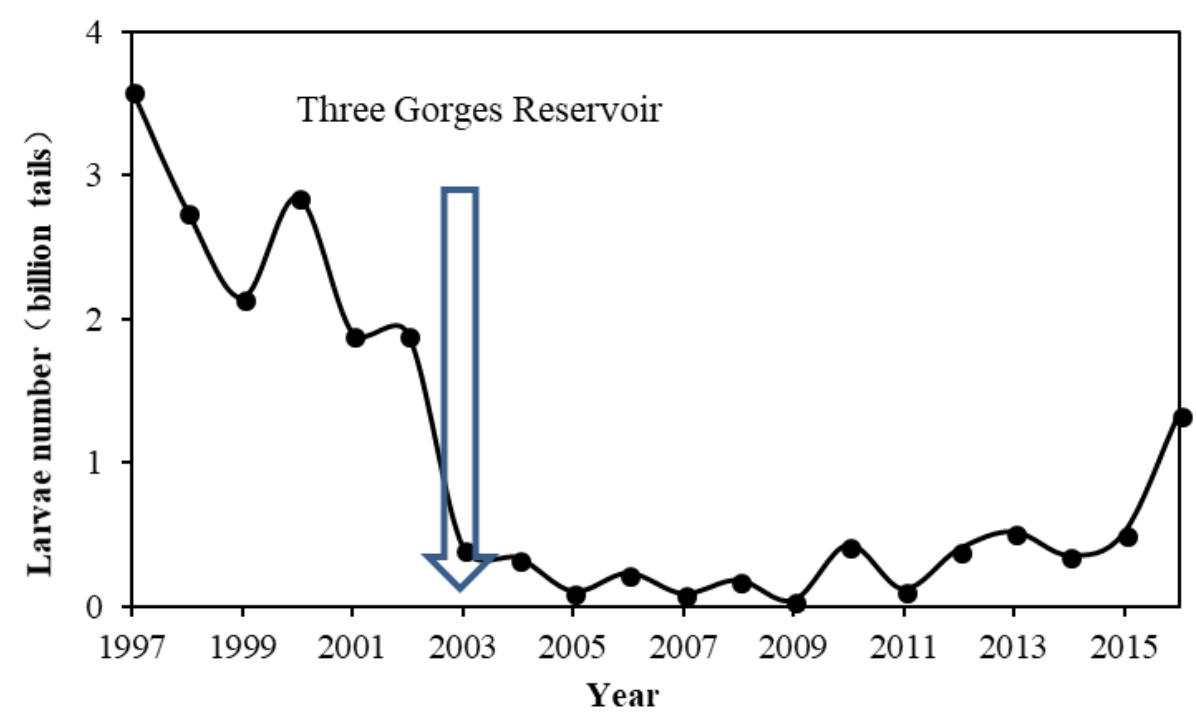

Figure 8. The monitoring results of four major Chinese carps' larvae runoff at the Jianli crosssection

As revealed in Fig. 8, after impoundment is initiated at Three Gorges Reservoir, significant adverse effect has been produced on the spawning and reproduction of four major Chinese carps. The larvae runoff during 2003-2016 displays a notable drop from 2.52 billion before impoundment to 0.29 billion after that. Since the larval fishes on Jianli cross-section are from the spawning sites in Yichang, Yidu, Jiangkou, Shishou and Diaoguan, the larvae runoff on this cross-section is found to be in dramatic declination with the lowest value ( 0.042 billion only) showing in 2009 , and no larval flood was detected for the first time in 2005. In 2010, 0.43 billion larval fishes were detected, which are significantly higher than that in 2009. The major overlying reason is that a lot of original parent fishes were released in Shishou and Jianli cross-sections in this year and great flood peaks appeared in late June and early July. In order to promote spawning and reproduction among four major Chinese carps, ecological scheduling experiments have been launched at Three Gorges Reservoir since 2011. According to the experiments, when four major Chinese carps begin spawning and reproduction, the discharged flow of dam is underregulated. As suggested by the monitoring results, the effect of ecological scheduling is obvious and the spawning scale of those four major Chinese carps gets improved. The larvae runoff during 2012-2016 was 0.397 billion, 0.52 billion, 0.355 billion, 0.51 billion and 1.34 billion, respectively.

Analysis of spawning fish composition among four major Chinese carps before and after impoundment at Three Gorges Reservoir

On the basis of data from several monitoring activities targeting four major Chinese carps in the history as well as those in recent four years, the composition of larval fishes of four major Chinese carps on Jianli-Sanzhou cross-section is demonstrated in Fig. 9. 


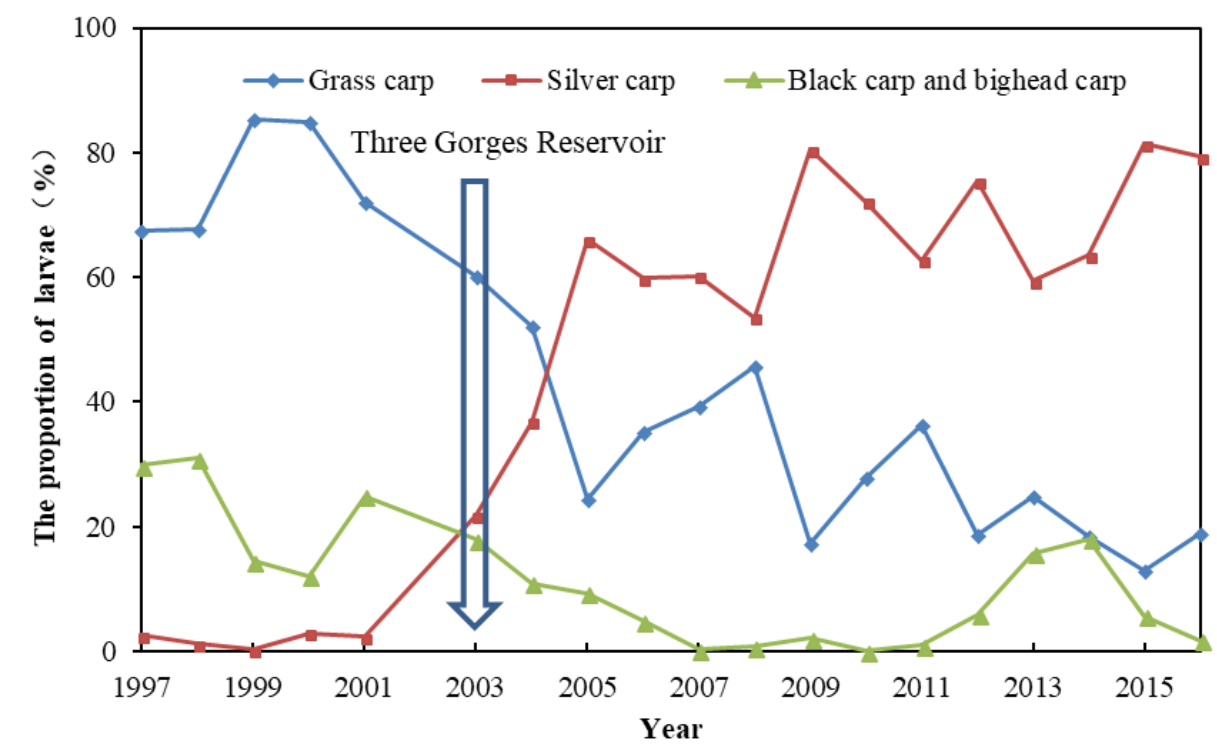

Figure 9. The fry type of four major Chinese carps at the Jianli cross-section

As shown in Fig. 9, before impoundment at Three Gorges Reservoir, the fishes on Jianli cross-section are mainly composed of grass carp and black carp, in which the former was overwhelming. The proportions of silver carp, black carp and bighead carp kept declining. By comparison, after the impoundment was started at Three Gorges Reservoir, great change occurred to the compositions of fishes in this cross-section, for the proportion of silver carp among larval fishes kept rising and reached $80.5 \%$ and $79.3 \%$, respectively, in 2009 and 2016; the proportion of grass carp declined from $60.2 \%$ in 2003 to $18.9 \%$ in 2016; and the proportions of black carp and bighead carp were reduced to the lowest value $(<2 \%)$.

\section{Discussion}

The correlation between the spawning and reproduction of four major Chinese carps and the hydrological conditions

\section{Hydrological factors affecting the reproduction of four major Chinese carps}

Studies have shown that the key hydrological indicators affecting the reproduction of domestic fish are flow rate growth and flood duration (Feng et al., 2013; Xie et al., 2015). In this study, the response relationship between the early resources of the four major Chinese carps to the hydrological process was analyzed, and it was also concluded that there was a significant positive correlation between the number of domestic fish eggs and the flow growth rate during the flood process. When the duration of rising water was $3 \mathrm{~d}$, the number of eggs and seedlings of domestic fish was low, and when the duration of rising water was $4 \mathrm{~d}$ or above, the number of eggs and seedlings of domestic fish was relatively high. Therefore, within a certain range of flow growth rate, the larger flow growth rate is beneficial to the reproduction of the four major Chinese carps. When the 
flood duration is too low, it cannot achieve the purpose of stimulating domestic fish to lay eggs.

\section{The role of ecological dispatch in the breeding of domestic fish in the Jianli section}

Four major Chinese carps in the spring water temperature rose to more than 18 degrees $\mathrm{C}$ to start spawning, 15 to 20 degrees $\mathrm{C}$ process for four major Chinese carps glands from stage 3 to stage 4 has an important impact, after more than 20 degrees $\mathrm{C}$, or even higher water temperature of 21 degrees $\mathrm{C}$, the sexual gland development of domestic fish will be quickly completed, sexual maturity of the four major Chinese carps pro-fish began to concentrate on breeding. During the ecological dispatch period from 2013 to 2017, the water temperature in the section of the River reached 18 degrees $\mathrm{C}$, and heated up one by one, and then reached more than 20 degrees $\mathrm{C}$, and the water temperature during the ecological dispatch period reached the basic requirements of the spawning water temperature of domestic fish.

According to the analysis of this study, when the ecological scheduling time of the Three Gorges Reservoir was in late June, the ecological scheduling promoted the formation of an effective water-inflation process in the Jianli River. The duration of water-inflation reached $4 \mathrm{~d}$ and above, and the flow growth rate reached $1600-2833 \mathrm{~m}^{3} /(\mathrm{s} \cdot \mathrm{d})$, which would stimulate the concentrated reproduction of domestic fish. The scholar has comprehensively analyzed the eco-environmental flow demand of domestic fish in the middle reaches of the Yangtze River before and after the operation of the Three Gorges ( $\mathrm{Li}$ et al., 2015). It was considered that the normal reproduction of domestic fish was from June 15 to July 20 every year, and the flood rate was $900-3100 \mathrm{~m}^{3} /(\mathrm{s} \cdot \mathrm{d})$. The conclusion of this study is within this range, and on this basis, the duration and growth rate of water inflation are further quantified. The results of this study can be used as an ecological regulation scheme for the breeding activities of the four major Chinese carps in the Jianli section of the Three Gorges Reservoir.

\section{Conclusions}

According to an analysis of frequency curves of major hydrological factors during spawning and reproduction period of four major Chinese carps, the proper flow rate for spawning and reproduction activities of those carps is $11,000-15,000 \mathrm{~m}^{3} / \mathrm{s}$, the proper flow rate rising amplitude is $5,000-13,000 \mathrm{~m}^{3} / \mathrm{s}$, proper daily flow rate rising speed is $100-1,000 \mathrm{~m}^{3} / \mathrm{s} \mathrm{d}$, and the proper flooding period is $4-8 \mathrm{~d}$. Among those hydrological factors, flooding period is in significant positive correlation with the spawning and reproductive quantity of four major Chinese carps with a correlation coefficient of 0.58 . The proper water level is $43.0-46.0 \mathrm{~m}$, proper rising range for water level is $2.0-4.0 \mathrm{~m}$ and proper daily rising range is $0.3-0.55 \mathrm{~m} / \mathrm{d}$. The proper sediment concentration is $0.01-0.21 \mathrm{~kg} / \mathrm{m}^{3}$. The spawning quantity of those fishes and sediment concentration are in significant positive relation with correlation efficient being 0.57 . The proper water 
temperature range for spawning and reproduction of four major Chinese carps is $22-24^{\circ} \mathrm{C}$. This last factor is not a critical one affecting the spawning and reproduction quantity of those carps, but it does influence the initial spawning and reproduction time of them.

In May and June, the monthly average flow rate, water level, water temperature and sediment concentration in Yichang section display a declining trend, among which the first three don't drop dramatically while the last one falls significantly at a confidence level over $95 \%$. The sediment concentration declines by $0.52 \mathrm{~kg} / \mathrm{m}^{3}$ and $0.95 \mathrm{~kg} / \mathrm{m}^{3}$ in May and June after the impoundment, and the declination is over $98 \%$ of the preimpoundment values. The great reduction in sediment concentration may change the riverbed structure of spawning sites for four major Chinese carps and produce a negative effect on the habitat conditions of them and further affect their spawning and reproduction activities.

An analysis of the spawning and reproduction conditions of four major Chinese carps in the middle reaches of Yangtze River reveals the number of spawning sites falls from 28 in the 1970 s to present 8 . The spawning scale also displays a dramatic declination, for as suggested by the cross-section monitoring results in Jianli, the spawning scale goes from 7.2 billion in 1986 to 0.52 billion now and even reaches 0.042 billion in 2009. In the larvae composition among four major Chinese carps, silver carp enjoys an absolute advantage, while the number of grass carp declines and that of dark carp and bighead carp drops sharply. The spawning and reproduction are also postponed with initial date postponed from the middle April in the past to the present middle May and spawning peak from the past middle May to the present late June.

In the future, we should combine engineering, non-engineering and management measures to comprehensively propose fish restoration and protection measures.

Acknowledgments. This work was supported by the National Nature Science Foundation of China (No. 51679090, 51609085, 51779094); the National Natural Science Foundation of Henan, China (No. 162102110015, 152300410113); Guizhou Water Resources Technology Project（KT202008).

Conflicts of Interests. The authors declare no conflicts of interests.

\section{REFERENCES}

[1] Agostinho, A. A., Pelicice, F. M., Gomes, L. C. (2008): Dams and The Fish Fauna of the Neotropical Region: Impacts and Management Related to Diversity and Fisheries. Brazilian Journal of Biology 68(4): 1119-1132.

[2] Ban, X., Jiang, L. Z., Zeng, X. H., Du, Y., Xiao, F., Ling, F. (2014): Quantifying The Spatio-Temporal Variation of Flow and Sediment in The Middle Yangtze River After the Impoundment of the Three Gorges. - Advances in Water Science 25(2): 650-657. (In Chinese). 
[3] Cai, Y. P., Yang, Z., Xu, W. (2017): Effect of Water Temperature Variation After Impoundment of the Three Gorges Reservoir on The Four Major Chinese Carps. Advanced Engineering Sciences 49(1): 70-77. (In Chinese).

[4] Cai, H. Y., Piccolroaz, S., Huang, J. Z., Liu, Z. Y., Liu, F., Toffolon, M. (2018): Quantifying The Impact of the Three Gorges Dam on The Thermal Dynamics of the Yangtze River. - Environ. Res. Lett. 13(5): 054016.

[5] Chen, W., Olden, J. D. (2017): Designing Flows to Resolve Human and Environmental Water Needs in a Dam-Regulated River. - Nature Communications 8(1): 2158.

[6] Dai, M., Wang, J., Zhang, M., Chen, X. (2017): Impact of The Three Gorges Project Operation on The Water Exchange Between Dongting Lake and The Yangtze River. International Journal of Sediment Research 32(4): 506-514.

[7] Feng, L., Hu, C. M., Chen, X. L., Zhao, X. (2013): Dramatic Inundation Changes of China's Two Largest Freshwater Lakes Linked to The Three Gorges Dam. - Environmental Science \& Technology 47(17): 9628-9634.

[8] Grill, G., Lehner, B., Thieme, M., Geenen, B., Tickner, D., Antonelli, F., Maced, H. E. (2019): Mapping The World's Free-Flowing rivers. - Nature 569: 215-221.

[9] Guo, W. X., Wang, H. X., Xu, J. X., Xu, J. X. (2011): Effects of Three Gorges Reservoir on The Downstream Eco-Hydrological Regimes During the Spawning of Important Fishes. - Journal of Hydroelectric Engineering 30(03): 22-26. (In Chinese).

[10] Herath, I. K., Wu, S., Ma, M., Huang, P. (2020): Reservoir $\mathrm{CO}_{2}$ Evasion Flux and Controlling Factors of Carbon Species Traced by $\Delta 13$ cdic at Different Regulating Phases of a Hydro-Power Dam. - Science of the Total Environment 698: 134184.

[11] Jiang, L. Z., Ban, X., Wang, X., Cai, X. (2014): Assessment of Hydrologic Alterations Caused by the Three Gorges Dam in the Middle and Lower Reaches of Yangtze River, China. - Water 6: 1419-1434.

[12] Li, Q., Yu, M., Lu, G., Cai, T., Xia, Z., Ren, L. (2011): Impacts of the Gezhouba and the Three Gorges Reservoirs on the Sediment Regime of the Yangtze River. - Hydrol. 403: 224-233.

[13] Li, Q. Q., Qin, H., Chen, G. C., Wang, B. (2012): Analysis on Hydrologic Alternation of Middle Yangtze River and its Impact on Fish. - Yangtze River 43(11): 87-89. (In Chinese).

[14] Li, J., Xia, Z. Q., Dai, H. C., Yi, W. (2013): Effect of the Three Gorges Reservoir Initial Filling on Downstream Habitat Suitability of the Typical Fishes. - Journal of Hydraulic Engineering 44(8): 892-900. (In Chinese)

[15] Li, C., Zhou, J., Ouyang, S., Wang, C., Liu, Y. (2015): Water Resources Optimal Allocation Based on Large-Scale Reservoirs in the Upper Reaches of Yangtze River. - Water Resour Manage. 29(7): 2171-2187.

[16] Li, Z., Ma, J., Guo, J., Paerl, H. W., Brookes, J. D., Xiao, Y., Fang, F., Ouyang, W., Lu, L. (2018): Water Quality Trends in the Three Gorges Reservoir Region Before and After Impoundment (1992-2016). - Ecohydrology \& Hydrobiology 203: 1-11.

[17] Peng, Q. D., Liao, W. G., Li, C., Yu, X. Z. (2012): Impacts of Four Major Chinese Carps' Natural Reproduction in the Middle Reaches of Yangtze River by Three Gorges Project Since the Impoundment. - Advanced Engineering Sciences 44(S2): 228-232. (In Chinese).

[18] Poff, N. L., Allan, J. D., Bain, M. B., Karr, J. R., Prestegaard, K. L., Richter, B. D., Sparks, R. E., Stromberg, J. C. (1997): The Natural Flow Regime. - Bioscience 47: 769-784.

[19] Wang, Y., Zhang, N., Wang, D., Wu, J., Zhang, X. (2018): Investigating the Impacts of Cascade Hydropower Development on The Natural Flow Regime in The Yangtze River, China. - Total Environ 624: 1187-1194.

[20] Xie, Y. H., Yue, T., Chen, X. S., Feng, L., Deng, Z. M. (2015): The Impact of Three Gorges Dam on the Downstream Eco-Hydrological Environment and Vegetation Distribution of East Dongting Lake. - Ecohydrology 8(4): 738-746. 
[21] Xue, L. Q., Zhang, H., Zhang, L. C., Chi, Y. X., Sun, C. (2017): Impact of Water Conservancy Projects on Eco-Hydrological Regime of Tarim River Based on Improved RVA Method. - Journal of Hehai Unviersity (Natural Sciences) 45(3): 189-196. (In Chinese).

[22] Yang, Z., Gong, Y., Dong, C., Qiao, H., Chen, X. J., Tang, H. Y. (2017): Temporal and Spatial Distribution of the Four Major Chinese Carp Species in Three Gorges Reservoir During the Normal Operating Period. - Journal of Hydroecology 38(5): 72-79. (In Chinese).

[23] Zhang, J., Sun, M., Deng, Z., Lu, J., Wang, D., Chen, L., Liu, X. (2017): Runoff and Sediment Response to Cascade Hydropower Exploitation in the Middle and Lower Han River, China. - Mathematical Problems in Engineering, ID: 8785236.

[24] Zhang, J., Feng, L., Chen, L., Wang, D., Dai, M., Xu, W., Yan, T. (2018): Water Compensation and its Implication of the Three Gorges Reservoir for The River-Lake System in The Middle Yangtze River, China. - Water 10(8): 10081011.

[25] Zhao, Y., Zhou, J. Z., Xu, K., Zhao, N. (2012): Ecological Operation of Three Gorges Reservoir for Protection of Four Major Chinese Carps Spawning. - Advanced Engineering Sciences 44(4): 45-50. (In Chinese). 